\title{
Samuel Beckett and the Islamic World: Connecting the Dots Through Beckett's Works and Reception
}

\author{
Dr Muhammad Saeed Nasir \\ Department of English, Emerson University, Multan \\ Ms. Misbah Ghufran \\ Department of English, University of Education, Lahore, Multan Campus \\ misbah.ghufran@ue.edu.pk \\ Muhammad Farhat Abbas \\ Visiting Faculty \\ Department of English, ISP Multan, farhatsoherwardi@yahoo.com
}

\begin{abstract}
The distinguished position of Samuel Beckett is due to his assignation of religious ideas. A quick closer look however reveals that Beckett has been studied from a Western perspective which is either religious or critical. A few studies on Beckett are from an Eastern viewpoint but Muslims' perspective still is missing. Keeping this research gap in mind, the current paper aims to determine the significant impact of the Islamic perspective on Beckett's works and how his works are adapted in various Muslim contexts. For this purpose, the adaptations of Waiting for Godot are used for finding out the connection between Beckett and the Islamic world. The findings of the paper highlight not only the presence of Beckett in the Islamic world but also the work offers rich signs in need to be traced.
\end{abstract} Contexts

Keywords: Beckett scholarship; Western lens; Islamic world, adaptations, Muslim

\section{Introduction}

Beckett has been critically appreciated mostly through Western political and philosophical viewpoints. As can be seen in the insightful works of Helene E. Baldwin's Samuel Beckett's Real Silence (1981), Shira Wolosky's Language Mysticism: The Negative Way of Language in Eliot, Beckett, and Celan (1995), Mary Bryden's Samuel Beckett and the Idea of God (1998) and Ian Bailey's Samuel Beckett and The Bible (2015) that Beckett's reference to religion or all his religious references have been interpreted from a Christian lens. The reason behind this convenient interpretation by Beckett scholars can be the immediate context of his works. Though a few of the scholars have tried a different interpretation of Beckett concerning the Eastern perspective. In this regard, the influences of Taoism, Hinduism and Buddhism can be observed on Beckett which were barely perceived by Beckett scholars in the past. In recent days, we can observe the trend of looking at Beckett through the perspective of East or Eastern traditions. Angela B. Moorjani's Beckett and Buddhism (2021) can be quoted as a representative example of this trend. However, it can be argued that Beckett scholarship still lacks the perspective of Islamic cultural and religious traditions. 


\section{Conceptual Framework}

The framework for the current study is selected from the field of psychology. It is related to culture and perception psychology. It is generally accepted idea that culture plays a critical role in making people who they actually are. It constitutes a particular environment of shared beliefs, ways of thinking of people and their interaction with each other. It is not surprising then that people from different cultures perceive the world and other people somewhat differently. Here the difference in the perception of people who belong to Western culture and people who belong to East Asian cultures can be highlighted. People from Western culture are individual-oriented whereas people from East Asian cultures have more collective view of people. The result of these differences in their perception is visible in the general behaviours of people (Ji, Peng, \& Nisbett, 2000; Lewis, Goto, \& Kong, 2008; Maddux \& Yuki, 2006). Frank (2008) also observes another dimension in the difference in perception. Frank analyses that our language impacts our ways of thinking. It is also been observed that the culture around us essentially shapes our brain and behaviour. As a result of which, people from different cultures process this world differently.

\section{Context of the Study}

Feldman's study of Beckett's early writings highlights the young Beckett's engagement with the work of Schopenhauer. He believes that there is an enormous influence of Schopenhauer on Beckett from 1930 onwards (Feldman, 2006, p. 12). For reference, Feldman quotes a letter of Beckett's to McGreevy in which he shows his fascination for Schopenhauer (p. 13). Deirdre Bair thinks that "Schopenhauer's ideas provided the philosophical foundation for Beckett" (Bair, 1990, p. 79). John Calder, on the other hand, thinks that it was Beckett's curiosity that made him follow the Buddhist and spiritual traditions (Calder, 2018, p. 5). In this regard, initial critical and fiction writings of Beckett, with pessimistic Proust monograph shows the influence of Schopenhauer's Buddhist-influenced models of the "will to live," (Feldman, 2006, p. 49) and Murphy's studies along with his 'swami' proposes, possibly, a satirical take on Yeats' Eastern philosophy. Thus, Leopardi's idea in 'A se stesso' that "In noi di cari inganni, / Non che la speme, il desiderio è spento" (Leopardi, 1923, p. 300), is encapsulated in Proust, "the wisdom... consists... not in the satisfaction but in the ablation of desire" (Beckett, 1931, p. 7). In How It Is, the idea is given voice vibrantly, "I too will renounce I will have no more desires" (Beckett, 1968, p. 62). 
The current efforts of Paul Foster's Beckett and Zen: A Study of Dilemma in the Novels of Samuel Beckett (1989), Lidan Lin's 'Samuel Beckett's Encounter with the East' (2010), Andy Wimbush's 'Biology, the Buddha and the Beasts: The Influence of Ernst Haeckel and Arthur Schopenhauer on Samuel Beckett's How It Is' (2013) and Pavneet Kaur's 'Samuel Beckett's 'The Way' and Stirring Still: Analysing the Self from 'Schopenhaurian Buddhist' Perspective"',(2017) have directed their attention towards this idea of studying Beckett through an Eastern perspective to contend this idea that Beckett was aware of Eastern custom of knowledge. It is due to the familiarity of Beckett with the Eastern tradition of knowledge that enriches his writings with new possible themes and makes it possible for scholars to interpret his work from different dimensions.

\section{Literature Review}

Beckett's scholarship has been extended to Eastern critical, religious and political traditions, other than that of Western stance. However, the Islamic perspective still is missing. It seems a bit unlikely phenomenon that too when throughout the $19^{\text {th }}$ century, there was a strong existence of Orientalism in Irish literature (Cochran, 2009). This trend was set by writers that include James Clarence Mangan, Lord Byron and Thomas Moore. Many Irish ancestors of Beckett have drawn Islamic themes through an Oriental lens, to transfer Anglo- Irish political squabble onto a suitable object. In this regard, Lalla Rookh (1817) of Thomas Moore, set in Persia, and Casabianca (1826) Felicia Dorothea Hemans, which is set in Egypt, has got the attention of Kamau Brathwaite. Particularly, Mangan, was a phenomenal translator (generally via German mediators) of Persian, Turkish and Arabic poetry, often using Arabic personae as mouthpieces for a displaced version of Anglo-Irish politics and its various colonial quarrels. Dublin University Magazines has published a lot of articles that are enlisted by Melissa Fegan to demonstrate how orientalism was rooted in Irish literature. Since its inception in 1833, this magazine has motivated Irish Victorian authors to produce work on 'representations of the East' (196-97). E. M. Cioran, who not only wrote Tears and Saints but also was connected to Beckett when Dream of Fair to Middling Women was being written by Beckett. Cioran placed Muslim mystics along with Christian saints, addressing the baseless idea that Western authors have connection only either with Jewish or Christian tradition only (Cioran, 1998, p. 5-6). In such conditions, the possibility of not knowing Islamic tradition by an Irish writer may be considered a mere exaggeration. 
Beckett's notes in the Arabic transcript and some other references to the Muslim scholars offer a positive start for further inquiries into this matter. The current paper offers an idea that how the relationship of Beckett with the Islamic world can be traced and how they can be linked together. The upcoming discussion can be separated into two sections; the first section deals with the idea of Beckett's direct connection with the Islamic world and Muslim writers and the second section deals with how Beckett can be connected with the Islamic world through the reception of Beckett in the Muslim world.

\section{Beckett's Direct Contact with the Islamic World}

Yannick Marien observes that Beckett uses an Arabic script in his notes on Dante's 'Inferno' (Marien, 2014, p. 1) and this stance has been supported by David Wheatley (1995) in his essay 'Beckett's mirlitonnades: A Manuscript Study'. This clue suggests that after studying the Muslim writers' works, Beckett might have tried to learn the transcription of Arabic. A keen observation leads us to spot the existence of Muslim writers in Beckett's works. In Dream of Fair to Middling Women, for example, he refers to "the darkest passages of...Hatiz, Saadi" (Beckett, 1993, p. 61). Interestingly, Beckett misspells Hafiz as Hatiz and considers both the poets as pessimistic, which in fact is quite misleading and is against the worldwide popularity of the poets. None of both, Hafiz and Saadi, convey the pessimistic message. John Pilling, however, observes that Beckett puts the category of Muslim writers in the wrong thematic list and misspelled the name of Hafiz (Pilling, 2004, p. 116).

In another famous work of Beckett, Happy Days, we find Winnie reflecting on the aspect of Willie's company. She seems to believe that being with him is bliss in the wilderness as she states:

I shall not trouble you again unless I am compelled to, just to know you are there within hearing and conceivably on the semi-alert is ... er ... paradise enow. [Pause.] (Beckett, 2012, p. 160).

Remarks of Winnie about Willie's reminds the verses from Edward Fitzgerald's translated work of Omer Khayyam, a Muslim poet.

A Flask of Wine, a Book of Verse- and

Thou Beside me singing in the Wilderness- 
And Wilderness is Paradise enow. (Fitzgerald, 2009, p. 21)

In All that Fall, there is the use of 'Ramadam' by Mrs. Rooney for being loud. She says, "I am sorry for all this ramdam" (Beckett, 2012, p. 186). The critics like that of Fletcher and Fletcher opine that ramdam which is a French word, "is traditionally associated with festivities occurring during the nocturnal hours of the Muslim Ramdan Fast” (Fletcher, 1985, p. 84). This use of the term in his work actually supports the idea that Beckett knew about Islam and Muslim traditions.

After the 1960s onwards, particularly after winning Nobel Prize in 1969, the Islamic world gained a newly achieved importance in the life of Beckett as he was mostly holidaying in Morocco and Tunisia. Although during his stay his interaction with the culture was casual, its effects of cultural connection can be traced in his letter to Barbara Bray. In the said letter, Beckett uses Hejira instead of the Gregorian calendar. He refers to $20^{\text {th }}$ February 1972 as Moharram 4, 1392 (Beckett, 2016, p. 283). In some of his other writings, his impressions of local culture can be traced. His French poem 'noire soeur' which is a part of the mirlitonnades sequence, actually is inspired by his Moroccan stay. In 1972, Beckett enjoyed some bird games in Morocco in which he "mistook storks [...] for vultures" and he recorded the happening by adding "a doodle to his letter to Barbara Bray to illustrate his foolishness" (Wheatley, 2017, p. 7). In one of his poems, 'dread nay' (1974), the storks are referred to in the fourth stanza.

faster than where

in hellice eyes

stream till

frozen to

jaws rail

gnaw gnash

teeth with stork

clack chatter (Beckett, 2007, p. 33)

Ruby Cohn claims that the "stanza offers horrific details of the head frozen in Dante's ninth circle" (Cohn, 2004, p. 327). However mostly, this stanza refers to the ways stark behaved while Beckett was observing them. 
The effect of African Muslim culture can also be dotted in Not I in which we find a Djellaba-clad figure. Explaining this figure, James Knowlson accounts that the Djellaba-clad figure was "an Arab woman waiting there for her child", which highly captivated Beckett during staying in Tunisia (Knowlson, 1996, p. 589).

The abovementioned references are few but can create a direct link between Samuel Beckett and the Islamic world. The other way of connecting Beckett could be the literary response of works in various Muslim contexts. In this regard, the prominent adaptations of Waiting for Godot offer us a lead to link Beckett with Muslims or the Islamic world. As a result, the following discussion traces how Beckett can be connected through the literary reception he achieves in various Muslim contexts.

\section{Beckett's Reception in the Muslim Contexts}

The discussion on Beckett's reception involving the Muslim contexts can be divided into two categories: Non-Asian Muslim context and Asian Muslim Context. The first section pinpoints how Waiting for Godot was adapted in Europe and the Middle East and the following discusses Waiting for Godot's reception in Asian Muslim contexts.

\section{- Waiting for Godot and its Reception in Non-Asian Muslim Context}

Waiting for Godot was produced by Ilan Ronen at the Municipal Theatre, Haifa (1984). The idea was to introduce Beckett for demonstrating the socio-political condition of the country. The play was translated into Arabic and Hebrew by Anton Shammas (Hutchings, 2005). It metaphorically demonstrated the relations between different communities with a particular focus on Muslims and Jews. Although the originality was marred due to this experimentation, the universality helped depict the state in which the people of Israel were living. This linguistic variety of the adaptations helped the spectators to 'identify emotionally' with the circumstances of the characters (Ronen, 1997). While the edition was an artistic achievement, it can be esteemed as food for thought. It helps the audience and readers in knowing how it helps depict the dilemma of Muslims and other groups who had had neither the privilege to theorize a meaningful version for their lives nor the liberty to settle a possibly different future that is offered by innate meaningless and insignificance of life. In the original text of Waiting for Godot, the central character wait for Godot, having the choice to wait or not but in the adaptation, the protagonist is not having any other choice but to wait for Godot. In the original 
scenario, the wait depicted is internal whereas, in the adapted situation, the wait is external as it is imposed one, with no choice. In this way, we can see a range of deviant sets of meanings. Beckett's Didi and Gogo try to give meaning to meaninglessness whereas Ronen's Didi and Gogo depict meaningful struggle against dominant forces and oppressed situations. Thus, Beckett's inclusion in the culture in a deviant way proves to be an attempt of observing the literary response of Beckett's works in the context involving Muslims.

In Sarajevo, Susan Sontag's adaptation of Waiting for Godot was another major attempt to involve the Muslim context though it was to unearth the plight of European citizens. Her experimentation of Waiting of Godot portrays a hopeless situation of war-inflicted Sarajevan people. With its depiction of the miserable situation of futility and imprisonment, the adaptation affords hope of redemption. There are certain changes made in the adaptation like the multiplicity of characters and confining the play as a single act. It was severely criticised by the stern Beckett scholars for the very reason although the play was adapted posthumously. However, she suggested that the modification was essential to spare the audience from the disappointment of the non-arrival of Godot even the second time as "the despair of Act 1 was enough for the Sarajevo audience" (Bowe, 2021, 267). Her defence finds roots in the famous idea by Vivian Mercier, "a play in which nothing happens twice" (Mercier, 1956, p. 6). However, it can be noted that Mercier, conversely, highlighted implicitly that no solid consequence is achieved by the end of both the acts but the characters neither departed nor left the place to utter darkness. Along with this, the changes could also be seen in censoring the religious content; however, this mindful omission can be justified as Sontag was aware of the diverse cultural and religious context of the spectators and reference to religious content could convey a negative message. On the other hand, Sontag (1994) claimed that the production was to express solidarity with subjugated citizens of Sarajevo, mostly Muslims, during the time of war.

The above conversation indicates that Waiting for Godot is an experimental play and this allows it to exceed the categorise of '-isms' such as existentialism, absurdism, and nihilism. This unique feature of Waiting for Godot fascinates the artists from every corner of the world to experience it in any form be it original or translated form. Thus, Waiting for Godot was brought from the French and English speaking world to the multilingual European countries along with Arabian Peninsula and Asia. 


\section{- Waiting for Godot and its Reception in Asian Muslim Context}

In Bangladesh, the translated English text of Waiting for Godot became part of the curriculum in the late 1970s. Mahmood (1993) observes that the reception of Waiting for Godot in the academics was extraordinary. This optimistic response helped to motivate Professor Kabir Chowdhry to translate Waiting for Godot with the name of Godor Pratikshaya into Bengali, which got published in 1981. Mahmood not only availed the opportunity to read Godor Pratikshaya but also attended the performance of Godor Pratikshaya. He assesses the reception of Godor Pratikshaya in two ways. Firstly, he identifies that 'long and frenzied speech' of Lucky were either condensed or omitted. Apart from this, he identifies that people of Bengali origin had to miss 'the biblical allusions, the reference to the crucifixion of the thieves, and to the Saviour, and the implication of Good Friday.' Mahmood does not explain anything about the exclusion of religious orientation and allusions. Secondly, he proposes us a deep vision into the performance of Godor Pratikshaya in 1984. Mahmood (1993) reveals that the theme of misery did not go unnoticed; rather, it encouraged the audience to recognise "the confusion, the uncertainty, the hopelessness, and despair of the tramps in the play" (Mahmood, 1993, 62). However, it is unfortunate that we are not aware of the fact that what kind of impression the audience took with them. Whether it was the confusion about their lives or the unhappy feelings for the characters. Nothing can be said for sure as it was not explained. This aspect might have brought a lively picture of what happened with the audience and how they responded to the play if it would have been addressed. It can be said then that the Bangladeshi version and conversion of Waiting for Godot under the name of Godor Pratikshaya highlights that its primary purpose was to introduce Beckett for entertaining purposes and literary reasons. The general appeal of the play did not fail in entertaining the people and urging them to search for the meanings and purpose of life by making an imaginative connection with the characters of Godor Pratikshaya. Although the religious invisibility allowed to adopt self-censorship yet this act might have led to the formation of ambiguity in the themes of the play. And this uncertainty of Waiting for Godot is its raison d'etre for being popular since the late 1950s. Knowlson (1996) opines that the durability of Waiting for Godot lies in its uncertainties and ambiguity. Much has been suggested rather than explicitly stated as the people can read into it what they want to read into it. Thus, it is expected that vulnerability and obscurity would make 
Waiting for Godot alive. Even if a culture does not appreciate Waiting for Godot, it would arise as Godor Pratikshaya.

Anwer Hussain Jafri, in Pakistan, produced Waiting for Godot under the name of Insha ka Intezaar [Waiting for Insha]. It has been staged twice in Pakistan and once in India as well (Nasir, 2021). Insha ka Intezaar reveals how average Pakistani men and women are facing the hardships of life and how their rights are unkempt by the powerful either patriarchs or rich. Amazingly, this adaptation of the play with the theme of religious exploitation is frequently displayed through the discriminatory constitutional laws and behaviour of the society. Jafri voices the agony and discontent of the common Pakistanis by aptly manipulating the universality of Waiting for Godot. Although the actions of the characters represent the unfair conditions of people in general, at the same time the frustration, the nothingness and helplessness represent the hollow hope for the future.

Moving around the paradoxical themes of void and hope, the adaptation cuts the religious symbolic text of Waiting for Godot. The outcome of this alteration, however, strongly instructs religious handling in the Pakistani society while evading Beckett's challenging religious material. For example, the speech of Lucky is being replaced by the ideas which are related to introducing Islamic laws in the constitution. Also, Naseebun (Lucky) portrays that religious discernment is common as she says that each one has created his own God. The representation of Pakistan's socio-religious and political reality is the leading theme in the play. As soon as the characters start realizing that their hope is hollow and they should keep it away from them, one of them brings back the idea of waiting for Insha so they start waiting for Insha again. Resultantly, they are unable to leave. Insha ka Intezaar's public reception had not been recorded but Pakistani leading newspapers gave proper space to the production. In The Dawn, Shanaz Ramzi acclaimed the adaptation for successfully mingling it with the religious 'scenario' of Pakistan and depicting 'the apathy, the gullibility of our people, and the state of hopelessness interlaced with an almost desperate conviction of better things to come' (Ramzi, 2008). In The News, Iram Noor Muzaffar identified that Insha ka Intezaar documented 'the poignancy, oppression, camaraderie, hope, corruption, exploitation and bewilderment' of humanity that reflect 'both comedy and pathos' (Muzaffar 2008, p. 4). 


\section{Conclusion}

In conclusion, it can be argued that the first section offers significant insight into the ways that trace Beckett's engagement with the Islamic world, which can create an intelligible bond between Beckett and the Islamic world. Thus, this section succeeds in contending that Beckett, time and again, expresses his vast knowledge about various issues, and it is not bound to the Western religious and intellectual traditions. Instead, there exists a substantial potential in Beckett, which can expand the horizons of contemporary Beckett scholarship. While the second section identifies numerous productions of Waiting for Godot involving Muslim contexts enabling us to create an indirect link of Beckett with the Muslim world. The productions of Waiting for Godot in Haifa and Sarajevo identify the issues of the Muslim audience and bring those issues to light. While the performance of Waiting for Godot in Haifa discovers major complicated difficulties of Arab communities, Sontag's of Waiting for Godot struggles to provide an aesthetic relief to the war-stricken ill-fated people, mostly Muslims. In all this process, it has been noted that the religious content was directly censored but the religious context of the audience led them to understand how the productions are related to them. On the other hand, Godor Pratikshaya and Insha ka Entezaar were staged entirely in the Muslim context of Islamic countries. Therefore, the explicit burden of religious context is not ambiguous. In both contexts, the adaptations ironically blue-pencil the religiously problematic ideas of Waiting for Godot. The expurgation of these ideas, however, resulted in the adoption of a coercive satirizing tone to highlight the plight of common citizens who, according to the adaptations' central message, are always misled by the religious authorities and the state. Although all the productions almost blue-pencils the religious material of the original text of Waiting for Godot, they have hardly been able to move beyond the religious sphere. Instead, the religious contexts of the adaptations lend more expressive insights to the audience. In simple words, Beckett's version of religious content goes missing, but the receivers were able to see and feel more clearly what was absent in the adaptations. These adaptations provide a link through which Beckett can be explored and any exploration that traces the impact of Islamic writers and countries on Beckett would be very welcomed and it can decrease the hostility of the Islamic world to challenging writers like Beckett. 


\section{References}

Bair, D. (1990). Samuel Beckett: a biography. Simon and Schuster.

Beckett, S. (2007). Collected poems in English and French. Grove Press.

------- (2012). The complete dramatic works of Samuel Beckett. Faber \& Faber.

(1993). Dream of Fair to Middling Women. Edited by Eoin O'Brien and Edith

Fournier, Calder,

(2016). The Letters of Samuel Beckett: Volume 4; Volumes 1966-1989. Edited by

George Craig, Martha Dow Fehsenfeld, Dan Gunn, and Lois More Overbeck,

Cambridge UP.

(1931). Proust, Chatto and Windus,.

-(1968). How It Is. John Calder.

-( 2002). Poems 1930-1989. Calder.

Bowe, N. M. (2021). Beckett and the Politics of Empathy in Site-Specific Theatre. In Beckett and Politics (pp. 263-280). Palgrave Macmillan, Cham.

Bressler Charles, E. (2011). Literary criticism: An introduction to theory and practice.

Bürger, P. (1984). Theory of the Avant-garde (Vol. 4). Manchester University Press.

Calder, J. (2018). Philosophy of Samuel Beckett. Alma Books.

Cioran, E. M. (1998). Tears and saints. University of Chicago Press.

Cochran, P. (Ed.). (2009). Byron and Orientalism. Cambridge Scholars Publishing.

Cohn, R. (2004). A Beckett Canon. U o Michigan P.

Connell, J. M. (2005). Continue to explore: in memory of Louise Rosenblatt (1904-2005).

Education and Culture, 21(2), 63-79.

Fegan, M. (2013). Every Irishman is an Arab’: James Clarence Mangan's Eastern ‘Translations.

Translation and Literature, 22(2), 195-214.

Feldman, M. (2006). Beckett's Books: A Cultural History of Samuel Beckett's 'Interwar Notes', Continuum.

Fletcher, B. S., \& Fletcher, J. (1985). A student's guide to the plays of Samuel Beckett. Faber $\&$ Faber.

Foster, P. (1989). Beckett and Zen: A Study of Dilemma in the Novels of Samuel Beckett.

Wisdom $\mathrm{P}$. 
Frank, M. C., Everett, D. L., Fedorenko, E., \& Gibson, E. (2008). Number as a cognitive technology: Evidence from Pirahã language and cognition. Cognition, 108(3), $819-824$.

Hutchings, W. (2005). Samuel Beckett's Waiting for Godot: a reference guide. Greenwood Ji, L.-J., Peng, K., \& Nisbett, R. E. (2000). Culture, control, and perception of relationships in the environment. Journal of Personality and Social Psychology, 78(5), 943-955.

Khayyam, O. (2009). Rubaiyat of Omar Khayyam. Translated by Edward Fitzgerald, edited by Daniel Karlin, Oxford P.

Knowlson, J. (1996). Damned to Fame: The Life of Samuel Beckett. Bloomsbury.

Leopardi, G. (1923). The Poems of Leopardi. Edited by Geoffrey L. Bickersteth, Cambridge UP.

Lewis, R. S., Goto, S. G., \& Kong, L. L. (2008). Culture and context: East Asian American and European American differences in P3 event-related potentials and selfconstrual. Personality and Social Psychology Bulletin, 34(5), 623-634.

Maddux, W. W., \& Yuki, M. (2006). The "ripple effect”: Cultural differences in perceptions of the consequences of events. Personality and Social Psychology Bulletin, 32(5), 669-683.

Mahmood, S. M. (1993). Beckett in Bangladesh. Samuel Beckett Today/Aujourd'hui, 2, 59-66. Marien, Y. (2014). “Samuel Beckett's Reading Notes.” Manuscript at Trinity, 14 March 2014, https://www.tcd.ie/library/manuscripts/blog/2018/03/samuel-beckettsreading-notes/. Accessed 13 Dec. 2018.

Mercier, M. 'The Uneventful Event', The Irish Times, 1956, p. 6

Nasir, M. S. (2021). Domesticating Beckett: The Religious and Political Complexity of Pakistan and Waiting for Godot. In Translating Samuel Beckett around the World (pp. 191-211). Palgrave Macmillan, Cham.

Pilling, J. (2004). A companion to 'Dream of fair to middling women'. Journal of Beckett Studies Books.

Ronen, I. (1997). Waiting for Godot as Political Theater. Directing Beckett, 239-249.

Sontag, S. (1994). Waiting for Godot in Sarajevo. Performing Arts Journal, 16(2), 87-106.

Tyson, L. (2015). Critical theory today: A user-friendly guide. Routledge. 
UNIVERSITY OF CHITRAL JOURNAL OF LINGUISTICS AND LITERATURE

VOL. 5 | ISSUE II | JULY - DEC | 2021

ISSN (E): 2663-1512, ISSN (P): 2617-3611

https://doi.org/10.33195/ill.v5ill.344

Wheatley, D. (1995). Beckett's mirlitonnades: A Manuscript Study. Journal of Beckett Studies, 4(2), 47-76.

Wheatley, D. (2017). Black diamonds of pessimism: The final correspondence of Samuel Beckett. TLS. Times Literary Supplement, (5938), 7-9.

\begin{tabular}{|l|l|}
\hline (C) @ 2021 by the author. Licensee University of Chitral, Journal of \\
$\begin{array}{l}\text { Linguistics \& Literature, Pakistan. This article is an open access article } \\
\text { distributed under the terms and conditions of the Creative Commons } \\
\text { Attribution (CC BY) (http://creativecommons.org/licenses/by/4.0/). }\end{array}$
\end{tabular}

